\title{
PENGGUNAAN METODE MIM- MEM UNTUK MENGEMBANGKAN KETERAMPILAN BERBICARA
}

\author{
Muhammad Iqbal \\ STIQ Amuntai, Kalimantan Selatan, Indonesia \\ Email: Iqbalhaja22@gmail.com
}

\begin{abstract}
Abstrak
Metode pembelajaran merupakan salah satu faktor penting dalam keberhasilan belajar bahasa Arab. Untuk keberhasilan pengajaran yang berkaitan dengan metode yang digunakan. Mim adalah singkatan dari mimicry yang artinya meniru dan mem adalah memorization yang artinya menghapal. Metode yang digunakan dalam mengajar keterampilan berbicara di sekolah biasanya sangat monoton dan bahkan penggunaan metode tidak sesuai dengan tujuan pembelajaran. Sehingga siswa merasa bosan dalam mempelajari bahasa Arab khususnya keterampilan berbicara yang membuat siswa merasa sulit untuk berbicara bahasa Arab karena masalah ini. Metode mim-mem berguna untuk melatih siswa untuk mengembangkan keterampilan komunikasi mereka. Karena setiap latihan-latihannya dilakuakan oleh seorang pengajar atau penutur asli yang dapat mendorong siswa dan terbiasa berbicara seperti penutur asli. Pokok masalah penelitian ini adalah: bagaimana efektifitas penggunaan metode Meniru dan Menghapal terhadap keterampilan bicara di sekolah MTsN Lampihong? Jenis penelitian ini adalah desain penelitian ekspremen dengan penggunaan pre-test dan post-test dalam satu kelompok. Sampel penelitian ini adalah sebagian siswa dari kelas dua di MTsN Lampihong. Hasil penelitian ini dapat disimpulkan sebagai berikut bahwa penggunaan metode mim-mem dalam rangka untuk meningkatkan pengembangan keterampilan berbicara sangat efektif.
\end{abstract}

Kata Kunci : Metode mim-mem, Keterampilan Berbicara

\section{Pendahuluan}

Bahasa Arab merupakan salah satu bahasa yang telah menyentuh berbagai ranah dunia. Selain sebagai bahasa media ajaran Islam, bahasa Arab juga telah berjasa dalam menjunjung tinggi sains dan teknologi, memperkaya khazanah budaya nasional dan media perubahan politik internasional yang semakin menampakkan peranannya dewasa ini. Sehingga bahasa Arab mengalami perkembangan yang sangat pesat.

Tujuan utama pembelajaran bahasa Arab adalah pengembangan kemampuan pelajar dalam menggunakan bahasa itu baik lisan maupun tulis. Kemampuan menggunakan bahasa dalam dunia pengajaran bahasa disebut keterampilan berbahasa. Keterampilan tersebut ada empat, yaitu 
Muhammad Iqbal: Penggunaan Metode Mim-Mem Untuk Mengembangkan Keterampilan Berbicara

keterampilan menyimak, berbiara, membaca dan menulis. Keterampilan menyimak dan membaca dikategorikan ke dalam keterampilan reseptif, sedangkan keterampilan berbicara dan menulis dikategorikan ke dalam keterampilan produktif.

Setiap keterampilan itu erat kaitannya satu sama lain, sebab dalam memperoleh keterampilan berbahasa, biasanya ditempuh melalui hubungan urutan yang teratur. Mula-mula pada masa kecil seorang anak belajar menyimak bahasa, kemudian berbicara, setelah itu ia belajar membaca dan menulis. Keempat keterampilan tersebut pada dasarnya merupakan suatu kesatuan. Berbicara adalah merupakan alat komunikasi sosial bagi manusia, hal ini merupkan bagian paling penting dalam praktek bahasa dan penggunaannya. ${ }^{1}$

Bahwasanya berbicara adalah warna yang paling penting dari kegiatan berbahasa untuk orang dewasa maupun anak-anak, dalam kehidupan kita berbicara lebih banyak digunakan dari pada menulis. Hal ini dapat dianggap bahwa berbicara adalah bentuk utama sebagai alat komunikasi bagi manusia. Tapi masalah sebenarnya dalam pembelajaran keterampilan berbicara adalah bahwa tujuan yang dipelajari siswa tidak jelas dan tidak spesifik. Di mana kemampuan siswa untuk percakapan dan diskusi dan potongan cerita dan menulis surat, laporan, meringkas. Ini adalah ajaran penting untuk pembelajaran bahasa Arab di sekolah. ${ }^{2}$

Keterampilan berbicara merupakan salah satu jenis kemampuan berbahasa yang ingin dicapai dalam pengajaran bahasa arab. Berbicara merupakan sarana utama untuk membina saling pengertian, komunikasi timbal balik, dengan menggunakan bahasa sebagai medianya. Kegiatan berbicara ini sebenarnya merupkan kegiatan menarik dalam kelas bahasa. Akan tetapi seringkali terjadi sebaliknya, kegiatan berbicara menjadi tidak menarik, tidak merangsang situasi suasana menjadi kaku dan akhirnya macet. Ini terjadi karena penguasaan kosakata dan pola kalimat oleh oleh siswa masih sangat terbatas. Namun demikian, kunci keberhasilan kegiatan tersebut sebenarnya ada pada pengajar. Apabila pengajar dapat merangsang situasi

1 Abdul Majid Sayyid Mansur, Sikolujiah Al-Wasail At-Ta'limiah Wa Wasail Tadris AlLugah Al-Arabiayah, (Riyadh: Darul Ma'arif, 1983), hal. 104

2 Ali Ahmad Madkur, Tadris Funun Al-Lugah Al-Arabiyah, (Al-Qahirah: Darul Fikri AlAraby, 2002), hal. 87 
Muhammad Iqbal: Penggunaan Metode Mim-Mem Untuk Mengembangkan Keterampilan Berbicara

pembelajaran menjadi hidup, dapat secara tepat memilih topik pembicaraan, teknik yang sesuai dengan tingkat kemampuan siswa, serta memiliki kreativitas dalam mengembangkan model-model pelajaran, maka tentu kemacetan itu tidak akan terjadi. ${ }^{3}$

Faktor lain yang penting dalam menghidupkan kegiatan bericara adalah keberanian murid dan perasaan tidak takut salah. Oleh karena itu pengajar dituntut mampu memberikan dorongan kepada siswa agar berani berbicara kendatipun dengan resiko salah. Kepada siswa hendaknya ditekankan bahawa takut salah adalah kesalahan yang paling besar. Secara umum tujuan latihan berbicara bahasa Arab untuk tingkat pemula, tingkat menengah dan tingkat lanjut adalah agar siswa mampu berkomunikasi lisan secara baik dan benar dengan ornag lain. ${ }^{4}$

Dalam kegitan belajar mengajar, sangat penting bagi guru untuk mempunyai berbagai metode. Ia harus mempunyai wawasan yang luas tentang bagaimanakah kegiatan belajar mengajar itu terjadi, dan langkahlangkah apakah yang harus ia tempuh dalam kegiatan tersebut. Jika seorang guru tidak mempunyai metode dalam mengajar, apalagi tidak menguasai materi yang hendak disampaikan, kegiatan belajar dan mengajar tersebut tidak akan maksimal, bahkan cenderung gagal. Proses pembelajaran keterampilan berbicara yang berlangsung kurang kreatif, akan menyebabkan kurang efektif, ujungnya pembelajaran jadi menegangkan. Ini tidak lain karena kurangnya perhatian pengajar dalam menganalisis siswa-siswanya. Bisa jadi pembelajaran yang seharusnya diterapkan untuk tingkatan mutaqaddim, seorang pengajar menerapkan pembelajaran tersebut di tingkatan mutawassit. Hal ini menjadikan siswa selalu merasa ketakutan setiap akan dimulainya pembelajaran keterampilan berbicara. Dan tak dapat dipungkiri bahasa Arab pada masyarakat, umumnya dianggap sebagai bahasa yang terlalu sulit untuk menjadi momok dalam materi pembelajaran. Imbasnya siswa tidak ada keinginan untuk mempelajari bahasa Arab.

Bagi seorang guru, wawasan belajar dan mengajar ini sebenarnya merupakan garis-garis besar haluan utuk bertindak dalam rangka mencapai

3 Syaiful Mustafa, Strategi Pembelajaran Bahasa Arab Inovatif, (Malang: UIN-Maliki Press, 2011), hal. 136

4 Syaiful Mustafa, Strategi Pembelajaran Bahasa Arab Inovatif, hal. 136 
Muhammad Iqbal: Penggunaan Metode Mim-Mem Untuk Mengembangkan Keterampilan Berbicara

tujuan yang telah ditetapkan sebelumnya. Jadi, seorang guru harus paham dan menguasai metode secara total. Jika kegiatan belajar dan mengajar dilakukan tanpa strategi maka sama halnya kegiatan tersebut terjadi dan dilakukan tanpa pedoman dan arah yang jelas. Akhirnya, target yang telah tersusun dan tertata rapi akan hancur dan tidak tercapai sama sekali. Sehubungan dengan hal tersebut, salah satu langkah agar seorang guru dapat memiliki dan mengembangkan metode belajar mengajar adalah dengan menguasai pengetahuan yang cukup mengenai hakikat belajar dan mengajar dengan berbagai cabang pendekatan yang ada di dalamnya. ${ }^{5}$

Dengan menguasai metode pembelajaran, seorang guru akan semakin terampil dalam menyesuaikan dengan materi pembelajaran. Sehingga, ia mudah memilih media dan menerapakannya dalam proses pembelajarannya tersebut. Jelasnya, apabila guru menguasai metode maka ia dapat memilih metode yang bagus, tepat, dan sesuai dengan materi pelajaran, bahan ajar, murid, situasi dan kondisi, serta media pembelajaran. ${ }^{6}$

Kenyataannya saat ini, pembelajaran bahasa arab justru dianggap sulit bagi sebagian peserta didik. Peserta didik cenderung takut bahkan kesulitan dalam mempelajari. Hal ini dapat menimbulkan rendahnya motivasi, minat dan keaktifan belajar peserta didik terhadap bahasa arab. Berkaitan dengan hal itu maka menjadi tugas bagi seorang guru yang kreatif, terampil dan professional untuk dapat membawa perubahan tingkah laku peserta didiknya.

Menurut hasil wawancara dengan guru mata pelajaran bahasa Arab MTsN Lampihong beliau menyampaikan bahwa sebagian besar peserta didiknya mempunyai minat dan tingkat perhatian yang kurang terhadap mata pelajaran Bahasa Arab. Ditemukan banyak peserta didik yang masih mengalami kesulitan dalam proses pembelajarannya sendiri, selama ini beliau menggunakan metode ceramah dan penugasan.

Berdasarkan pengamatan pembelajaran di MTsN Lampihong, peserta didik kurang semangat mengikuti pelajaran Bahasa Arab, ini terlihat ketika guru sedang menjelaskan materi terdapat beberapa peserta didik yang asik bermain sendiri dan ramai dengan teman sebangkunya. Dalam proses pembelajarannya guru hanya sekilas menjelaskan materi dan membacakan

${ }^{5}$ Anissatul Mufarokah, Strategi Belajar Mengajar (Yogyakarta: TERAS, 2009),hal. 2

6 Ulin Nuha, Metodologi Super Efektif Pembelajaran Bahasa Arab(Yogyakarta: DIVA Press, 2012), hal. 157 
Muhammad Iqbal: Penggunaan Metode Mim-Mem Untuk Mengembangkan Keterampilan Berbicara

mufradat. Selanjutnya peserta didik diminta untuk mengerjakan soal latihan di dalam buku tugas secara mandiri.

Hasil belajar peserta didik pada ulangan harian mata pelajaran Bahasa Arab pun kurang begitu memuaskan. KKM (Kriteria Ketuntasan Minimal) yang ditetapkan pada mata pelajaran bahasa Arab di MTsN Lampihong adalah 64 . Dari jumlah peserta didik 20 orang hanya terdapat 4 orang peserta didik yang mendapat nilai di atas KKM. Sedangkan yang lainnya mendapatkan nilai dibawah KKM.

Oleh karena itu, hendaknya seorang guru harus bisa menguasai berbagai jenis metode pembelajaran yang bisa langsung dipraktekkan untuk menjalankan proses belajar mengajar dengan siswa. salah satu penggunaan metode yang bisa digunakan adalah metode meniru dan menghafal (mimicry and memorization). Metode meniru dan menghafal (mimicry and memorization) termasuk metode klasik, namun bukan berarti tidak efektif dalam pembelajaran Bahasa Arab. Metode Mimicry-Memorization cocok digunakan dalam pembelajaran bahasa, terlebih lagi bahasa asing. Ketika seorang anak belajar berbicara, hal pertama yang dia lakukan adalah meniru bahasa yang didengarnya dari ibunya. Kemudian bahasa itu diucapkan berulang-ulang hingga masuk kedalam memorinya. Jadi meniru dan menghafal merupakan hal dasar yang dilakukan anak dalam proses pemerolehan bahasanya. Begitu pula proses yang terjadi ketika dia belajar bahasa asing.

\section{Kajian Teori}

\section{Tujuan keterampilan berbicara}

Secara umum, keterampilan berbicara bertujuanagar para pelajar mampu berkomunikasi secara lisan dengan baik dan wajar, tujuan dari keterampilan berbicara mencakup beberapa hal antara lain sebagai berikut: ${ }^{7}$

7 Iskandarwassid, dkk. Strategi Pembelajaran Bahasa (Bandung: Rosdakarya. 2009) hal. 242 
Muhammad Iqbal: Penggunaan Metode Mim-Mem Untuk Mengembangkan Keterampilan Berbicara

\section{a. Kemudahan berbicara}

Peserta didik harus mendapat kesempatan yang besar untuk berlatih berbicara sampai mereka mampu mengembangkan keterampilan ini secara wajar, lancar, dan menyenangkan, baik dalam kelompok kecil maupun dihadapan pendengar umum yang lebih besar jumlahnya. Para peserta didik perlu mengembangkan kepercayaan yang tumbuh melalui latihan.

b. Kejelasan

Dalam hal ini peserta didik berbicara dengan tepat dan jelas, baik artikulasi maupun diksi kalimat-kalimatnya. Gagasan yang diucapkan harus tersusun dengan baik. Agar kejelasan dalam berbicara tersebut dapat dicapai. Maka dibutuhkan berbagai macam latihan terus menerus dan variatif. Latihan tersebut bisa melalui diskusi, pidato, dan debat. Karena dengan latihan seperti ini dapat mengatur cara berfikir seseorang dengan sistematis dan logis.

\section{c. Bertanggung jawab}

Latihan berbicara yang bagus menekankan pembicara untuk bertanggung jawab agar berbicara secara tepat, dan dipikirkan dengan sungguh-sungguh mengenai apa yang menjadi topik pembicaraan, tujuan pembicaraan, siapa yang diajak berbicara, dan bagaimana situasi pembicaraan serta momentumnya pada saat itu. Latihan demikian akan menghindarkan seseorang dari berbicara yang tidak bertanggung jawab atau bersilat lidah yang mengelabui kebenaran.

d. Membentuk pendengaran yang kritis

Latihan berbicara yang baik sekaligus mengembangkan keterampilan menyimak secara tepat dan kritis juga menjadi tujuan utama program pembelajaran ini. Di sini peserta didik perlu belajar untuk dapat mengevaluasi kata-kata yang telah diucapkan, niat ketika mengucapkan, dan tujuan dari pembicaraan trsebut.

e. Membentuk kebiasaan

Kebiasaan berbicara bahasa Arab tidak dapat dicapai tanpa ada niat yang sungguh-sungguh dari peserta didik itu sendiri. Kebiasaan ini bisa diwujudkan melaui interaksi dua orang atau lebih yang telah disepakati sebelumnya, tidak harus dalam komunitas yang besar. Dalam menciptakan kebiasaan berbahasa 
Muhammad Iqbal: Penggunaan Metode Mim-Mem Untuk Mengembangkan Keterampilan Berbicara

Arab ini yang dibutuhkan adalah komitmen, komitmen ini bisa dimulai dari diri sendir, kemudian komitmen ini berkembang menjadi kesepakatan dengan orang lain untuk berbasaha Arab secara terus menerus, ini lah yang disebut dengan menciptakan lingkungan berbahasa yang sesungguhnya.

Dengan melihat tujuan pembelajaran di atas maka seorang guru harus bisa memilih atau menggunakan metode,teknik atau strategi yang sesuai agar tujuan pembelajaran berbicara bisa tercapai secara efektif.

\section{Metode Keterampilan Berbicara}

Berbicara menggunakan bahasa asing bukanlah hal yang mudah, sebagaimana jika berbicara menggunakan bahasa ibu. Oleh karena itu, hendaknya dalam mengajarkan keterampilan berbicara perlu memperhatikan metode pengajaran yang sesuai dengan kemampuan anak didik. Harus diakui bahwa tidak semua orang mampu dengan baik dan sempurna dalam berbicara menggunakan bahasa asing, termasuk dalam bahasa Arab. Di antara mereka ada yang mempunya bahasa asing sangat bagus, ada yang sederhana, dan ada yang masih sebagai pemula, bahkan ada yang masih sama sekali belum bisa. Oleh karena itu, dalam pembelajarannya, hendaknya terdapat spesifikasi teknik yang bisa dipakai oleh pemula (mubtadi'), menengah (mutawasit), dan tingkat atas (mutaqaddim). ${ }^{8}$

Adapun penjelasannya sebagai berikut: ${ }^{9}$

\section{a. Tingkat Pemula (Mubtadi')}

Bagi tingkat pemula dapat digunakan metode atau teknik ulang ucap, lihat ucap, permainan kartu kata, wawancara, permainan memori, reka cerita gambar, biografi, manajemen kelas, bermain peran. Atau juga bisa dengan langkah-langkah seperti ini:

1) Siswa diminta untuk belajar mengucapkan kata, menyusun kalimat dan mengungkapkan pikiran secara sederhana.

2) Guru mengajukan pertanyaan-pertanyaan yang harus dijawab oleh siswa sehingga berakhir membentuk sebuah tema yang sempurna.

3) Guru mulai melatih bicara dengan memberi pertanyaan sederhana.

4) Guru bisa menyuruh siswa menjawab latiahn-latihan syafahiyah dengan menghafalkan percakapan, atau menjawab pertanyaan yang berhubungan dengn isi teks yang telah siswa baca.

8 Ulin Nuha, Metodologi Super Efektif Pembelajaran Bahasa Arab. hal. 100

9 Dewirohmah.wordpress.com 
Muhammad Iqbal: Penggunaan Metode Mim-Mem Untuk Mengembangkan Keterampilan Berbicara

b. Tingkat menengah (Mutawasit)

Untuk tingkat menengah, dapat digunakan metode atau teknik-teknik dramatisasi, elaborasi, reka cerita gambar, biografi, wawancara, permainan kartu kata, diskusi, pecakapan satu pihak, pidato pendek, melanjutkan cerita. Atau juga bisa dengan langkah-langkah sebagai berikut:

1) Belajar berbicara dengan bermain peran.

2) Berdiskusi dengan tema tertentu

3) Berbicara tentang peristiwa yang terjadi pada siswa.

4) Bercerita tentang informasi yang telah didengar dari televisi, radio, atau lain-lainya.

c. Tingkat atas (Mutaqaddim)

Sedangkan dalam tingkat paling tinggi dapat digunakan metode atau teknik dramatisasi, elaborasi, reka cerita gambar, biografi, bermain peran, diskusi, wawancara, pidato, melanjutkan cerita, talk show, dan debat.

Pada tahap permulaan, latihan berbicara dapat dikatakan serupa dengan latihan menyimak. Sebagaimana telah dikatan sebelumnya, dalam latihan menyimak ada tahapan mendengarkan dan menirukan. Latihan mendengarkan dan menirukan ini merupakan gabungan antara latihan dasar untuk kemahiran menyimak dan kemahiran berbicara. Namun harus disadari bahwa tujuan akhir dari keduanya berbeda, tujuan akhir mnyimak adalah kemampuan memahami apa yang disimak. Sedangkan tujuan akhir latihan brbicara adalah kemampuan (ta'bir) dalam mengemukakan ide, pikiran, dan pesan kepada orang lain. Keduanya merupakan syarat mutlak bagi sebuah komunikasilisan yang efektif secara timbal balik. ${ }^{10}$

\section{Metode Mim-Mem untuk mengembangkan keterampilan berbicara}

Metode mim-mem sebenarnya merupakan singktan dari Mimicry (yang artinya meniru) dan Memorization (yang bebarti menghafal), ${ }^{11}$ atau dalam bahasa Arab bisa disebut dengan al-muhakah wal-hifzh. Metode ini merupakan latihan meniru dan menghapalkan dialog-dialog mengenai berbagai macam situasi dan kesempatan melalui latihan ini seorang pelajar dapat mencapai kemahiran yang baik dalam percakapan yang dilakukan secara wajar dan tidak dibuat-buat. Walaupun awalnya memang dipola berdasarkan hapalan,

10 Ahmad Fuad Effendy, Metodologi Pengajaran Bahasa Arab(Malang: Misykat, 2009), hal. 114

11 Ulin Nuha, Metodologi Super Efektif Pembelajaran Bahasa Arab. hal. 215 
Muhammad Iqbal: Penggunaan Metode Mim-Mem Untuk Mengembangkan Keterampilan Berbicara

namun jika dilkukan latihan secara terus menerus akan menjadi kemampuan berkomunikasi secara wajar.Metode ini juga sering kali disebut metode informant-drill method. Dikatakan demikian karena setiap latihan-latihannya dilakukan oleh seorang pengajar dan informan penutur asli atau native speaker. memorization method,-mimicry. Jadi metode ini sebenarnya adalah ${ }^{12}$ yang kemudian disingkat menjadi mim-mem method.

Sebagai implikasinya metode ini menekankan penelaahan dan pendeskripsian suatu bahasa yang akan dipelajari dengan memulainya dari sistem bunyi (fonologi), kemudian sistem pembentukan kata (morfologi), dan sistem pembentuksn kalimat (sintaksis). Karena menyangkut struktur bahasa keseluruhan, maka dalam hal ini juga ditekankan sistem tekanan, nada, dan lain-lain. Maka bahasa tujuan diajarkan dengan mencurahkan perhatian pada lafal kata, dan pada latihan berkali-kali (drill) secara intensif. Bahkan drill inilah yang biasanya dijadikan teknik utama dalam proses belajar mengajar. Drill ialah suatu teknik pengajaran bahasa yang dipakai oleh semua guru bahasa pada suatu waktu untuk memaksa para pelajar mengulang dan mengucapkan suatu pola kalimat dengan baik tanpa kesalahan. Mengadakan drill dengan konsisten akan melahirkan kebiasaan yang baik dalam berbahasa. 13

Adapun ciri-ciri dari metode ini adalah sebagai berikut; ${ }^{14}$

a. Kegiatan belajar mengajar didemonstrasikan, drill gramatika dan struktur kalimat, ucapan atau pronunciation drill, latiham menggunakan kosakata dengan cara menirukan guru, dan native speaker.

b. Pada saat drill, native speaker atau native informant bertindak sebagai drill master, yaitu dengan cara mengucapkan beberapa kalimat, dan peserta didik menirukannya sampai beberapa kali hingga hafal.

c. Garamatika diajarkan secara tidak langsung melalui kalimat-kalimat yang dipilih sebagai model atau pola.

d. Pada tingkat lanjutan, kegiatan dilakukan dengan cara diskusi atau dramatisasi.

12 A. Akrom Malibary dkk., Pedoman Pengajaran Bahasa Arab Pada Perguruan Tinggi Agam/I.A.I.N (Jakarta: Depag R.I., 1976) hal. 101

13 Acep Hermawan, Metodologi Pembelajaran Bahasa Arab. (Bandung: PT Remaja Rosdakarya, 2013) hal. 185-186

14 Juariyah Dahlan, Metode Belajar Mengajar Bahasa Arab (Surabaya: AL-IKHLAS, 1992), hal. 117 
Muhammad Iqbal: Penggunaan Metode Mim-Mem Untuk Mengembangkan Keterampilan Berbicara

e. Metode bervariasi karena bisa digunakan rekaman-rekaman dialog dan drill yang disebut audio-lingual method atau disebut juga aural-oral approach.

\section{Langkah-langkah penggunaan metode Mim-Mem}

Terlihat bahwa metode mim-mem pada dasarnya tidak hanya menekankan latihan peniruan dan penghpalan para pelajar untuk membentuk kecakapan berbahasa, tetapi juga kecermatan pengajar dalam membimbing mereka sangat diperhatikan. Oleh sebab itu seorang penhajar harus benarbenar menguasai prinsip-prisip itu.

Untuk mencapai tujuan yang diharapkan, diperlukan langkah-langkah yang dianggap cocok. Mislanya saja langkah yang dipilih adalah sebagai berikut: 15

a. Pendahuluan, memuat berbagai hal yang berkaitan dengan materi yang kan disajikan baik berupa appersepsi, atau tes awal tentang materi, atau yang lainnya.

b. Penyajian dialog atau bacaan pendek yang dibacakan oleh guru berulang kali, sedangkan pelajar menyimaknya tanpa melihat pada teksnya.

c. Peniruan dan penghapalan dialog atau bacaan pendek dengan cara meniru setiap kalimat secara serentak dan menghapalkannya.

d. Penyajian pola-pola kalimat yang terdapat dalam dialog tau bacaan yang dianggap sulit karena terdapat struktur atau ungkapan-ungkapan yang sulit. Hal ini bisa dikembangkan dengan drill dengan metode ini dilatih struktur dan kosa kata. Contohnya sebagai berikut:

Drill yang mengganti satu unsur:

$\begin{array}{llll}\text { Guru } & : & \mathrm{S}_{1} & \text { صحيح،.. نحن... } \\ \text { Pelajar } & : & \mathrm{R}_{1} & \text { (أنا تلميذ } \\ \text { Guru } & : \text { (memberi penguatan dan rangsangan baru): } & \mathrm{S}_{2} \\ \text { Pelajar } & : & \mathrm{R}_{2} & \\ \text { Dan seterusnya. } & & \end{array}$

Drill tanya jawab:
Guru
$\mathrm{S}_{1}$
يكتب أحمد الدرس في الفصل
Guru
$\mathrm{S}_{2}$

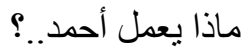

${ }^{15}$ Acep Hermawan, Metodologi Pembelajaran Bahasa Arab, hal. 188-190 
Muhammad Iqbal: Penggunaan Metode Mim-Mem Untuk Mengembangkan Keterampilan Berbicara

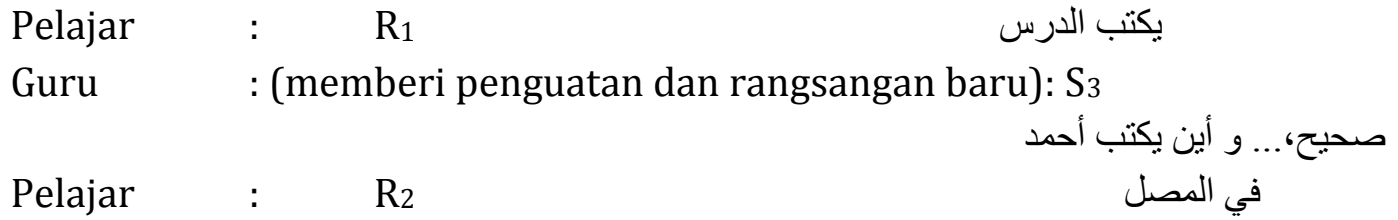
dan seterusnya.

Drill menyatukan kalimat

Guru : $\quad \mathrm{S}_{1}$

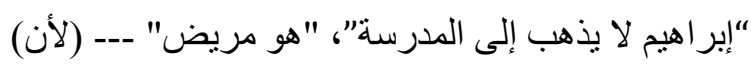

Pelajar $\quad: \quad R_{1}$

Guru $\quad: \quad S_{2}$

إبر اهيم لا بذهب إلى المدرسة لأنه مريض

Pelajar $\quad: \quad \mathrm{R}_{2}$

"إبر اهيم مريض"، "إبر اهيم يقر أ الكتاب في بيته" ---- (لكن)

"إبر اهيم مريض لكنه يقر أ الكتاب في بيته

dan lain-lain.

Keterangan : $\mathrm{S}=$ Stimulus; $\quad \mathrm{R}=$ Respon

e. Dramatisasi dari dialog atau bacaan yang sudah dilatihkan di atas. Pelajar yang sudah hapal disuruh mempergunakannya di muka kelas.

f. Pembentukan kalimat-kalimat lain yang sesuai dengan pola-pola kalimat yang sudah dilatihkan.

g. Penutupan (jika diperlukan) misalnya dengan memberikan tugas untuk dikerjakan di rumah. Dalam hal ini pelajar disuruh berlatih kembali dlam menggunakan pola-pola yang sudah dipelajarinya disekolah.

\section{Kelebihan dan kekurangan metode mim-mem}

Berdasarkan karakteristik metode ini, bisa dilihat beberapa aspek kelebihan dan kekurangannya:

Aspek kelebihannya antara lain: ${ }^{16}$

a. Para pelajar jadi terampil dalam membuat pola-pola kalimat yang sudah di-drill.

b. Para pelajar mempunyai lapal yang baik dan benar.

c. Para pelajar tidak tinggal diam dalam dialog tetapi harus terus menerus memberi respon pada rangsangan yang diberikan oleh guru.

16 Acep Hermawan, Metodologi Pembelajaran Bahasa Arab. hal. 191 
Muhammad Iqbal: Penggunaan Metode Mim-Mem Untuk Mengembangkan Keterampilan Berbicara

d. Para pelajar memperoleh keterampilan secara langsung atau praktis dalam berbahasa asing. ${ }^{17}$

Aspek kelemahannya antara lain: 18

a. Metode ini memerlukan seorang guru yang benar-benar aktif dalam berbahasa asing.

b. Para pelajar cenderung untuk memberi respon secara serentak atau secara individu seperti "membeo", dan sering tidak mengetahui makna yang diucapkannya.

c. Pada umumnya, kemampuan aplikatif bahasa asing anak didik sangat ditentukan oleh faktor motivasi dari pihak guru. Artinya, seorang guru harus memberikan motivasi pada anak didiknya disela-sela pelajaran.

d. Metode ini berpendirian bahwa jika pada tahap-tahap awal para pelajar tidak atau belum mengerti makna dari kalimat-kalimat yang ditirunya, tidak dianggap sebagai hal yang meresahkan. Selanjutnya dengan menyimak yang dikatakan oleh guru, merespon yang benar, dan melakukan semua tugas tanpa salah, pelar sudah dianggap belajar bahasa tujuan dengan benar. Jika dianalisa pendirian ini kurang dapat diterima, sebab meniru tanpa mengetahui makna adalah suatu aktifitas yang mubadzir. Kecuali itu hapalan pola-pola kalimat dengan ucapan yang baik dan benar belum berarti bahwa para pelajar dengan sendirinya akan mampu berkomunikasi dengan wajar. Oleh sebab itu diperlukan bimbingan yang intensif dalam mencapai kemampuan komunikasi ini.

\section{Aspek-aspek yang perlu diperhatikan dalam pembelajaran berbicara}

Ada beberapa aspek yang harus diperhatikan oleh pengajar dalam pembelajaran berbicara, antara lain: ${ }^{19}$

1. Dalam melatih percakapan, pengajar hendaknya memberikan contoh percakapan terlebi dahulu dengan intonasi dan ekspresi yang benar-benar menggambarkan pengertian secara tepat. Dalam percakapan ini jangn sampai dilupakn aspek budaya orang arab (penutur asli) yang sudah lazim dalam percakapan dan dianggap sebagai sopan santun dalam pergaulan.

17 Ahmad Muhtadi Anshor, Pengajar Bahasa Arab; Media Dan Metode-Metodenya (Yogyakarta: TERAS, 2009), hal. 76

18 Acep Hermawan, Metodologi Pembelajaran Bahasa Arab. hal. 191

19 Syaiful Mustafa, Strategi Pembelajaran Bahasa Arab Inovatif, hal. 152-153 
Muhammad Iqbal: Penggunaan Metode Mim-Mem Untuk Mengembangkan Keterampilan Berbicara

2. Dalam peckapan bebas hendaknya pengajar memberikan perhatian khusus kepada siswa yang pemalu. Berikan dorongan kepada mereka untuk tampil dan berbicara. Juga harus dihindari terjadinya monopoli pembicaraan oleh beberapa siswa saja.

3. Dalam mengikuti percakapan atau pembicaraan siswa, sebaiknya pengajar bersabar untuk tidak terburu-buru memberikan pembetualan setiap kali siswa berbuat kesalahan. Tunggulah sampai sorang siswa selesai berbicara atau bahkan sampai seluruh kegiatan selesai. Sebab hal itu di samping bisa mengganggu jalannya kegitan juga mempengaruhi keberanian siswa.

4. Susunan kelas hendaknya diubah sedemikian rupa sehingga kemungkinan partisitipasi seluruh anggot kelas dalam kegitan pembelajaran. Buatalah bentuk lingkaran, tapal kuda atau setengah lingkaran. Bahkan kalau memungkinkan kegiatan percakapan bisa dilakuakan di tempat terbuka di luar kelas, untuk menghindari kejenuhan.

\section{Metode Penelitian}

Jenis penelitian ini adalah kuantitatif, adapun Pendekatan yang digunakan untuk penelitian ini adalah pendekatan eksperimen, Pendekatan ini disebut eksperimen karena satu-satunya penelitian yang dapat digunakan untuk menguji hipotesis hubungan antara sebab dan akibat. Dalam studi eksperimental, peneliti biasanya mengendalikan satu atau lebih variabel independen. ${ }^{20}$

Desain penelitian adalah Semua proses yang diperlukan dalam pelaksanaan penelitian. Penelitian eksperimen mempunyai berbagai macam desain. Penggunaan desain tersebut disesuaikan dengan aspek penelitian serta pokok masalah yang ingin di ungkapkan. Desain penelitian yang digunakan dalam penelitian ini adalah pre-test, post-test, group design yaitu kelompok diberikan tes awal untuk mengukur kondisi awal. Selanjutnya pada kelompok eksperimen diberikan perlakuan. Sesudah selesai perlakuan kelompok diberi tes lagi sebagai tes akhir, disini ada perbedaan antara kelompok eksperimen dan kelompok kontrol. ${ }^{21}$

$$
\text { 20 عبد الرمن عدس: أساسيات البحث التربوي، عمان: دار الفرقان، ط3، 1999م، ص } 184 .
$$

${ }^{21}$ Sugiono, Metode Penelitian pendidikan, Pendekatan Kuantitatif, Kualitatif, dan R\&D (Bandung: Alfabeta, 2012), hal. 112-113. 
Muhammad Iqbal: Penggunaan Metode Mim-Mem Untuk Mengembangkan Keterampilan Berbicara

Variabel dalam penelitian ini menggunakan 2 (dua) variabel independen dan dependen, independen adalah faktor yang kami ingin mengukur sejauh mana dampaknya terhadap situasi, yang disebut variabel eksperimental. Dan variabel dependen Adalah faktor yang dihasilkan dari pengaruh faktor independen. Pertama, variabel independen: Metode Mim-mem yang ingin peneliti terapkan. Kedua, variabel dependen: Ini adalah hasil dari pengembangan keterampilan berbicara dalam bentuk Mim-mem.

Sedangkan, sumber data dalam penelitian ini terbagi menjadi dua, yaitu: pertama, sumber data primer dalam penelitian ini adalah sumber data yang diperoleh langsung dari informan di lapangan sesuai dengan permasalahan yang dibahas dalam penelitian ini. Data tersebut bersumber dari hasil wawancara peneliti dengan guru bahasa arab, kepala sekolah, perwakilan peserta didik dan pihak-pihak yang dianggap terkait dengan permasalahan penelitian ini. Dan kedua, Data Sekunder adalah sumber data tambahan di luar kata-kata dan tindakan yakni sumber data tertulis yang diperoleh dari hasil dari pelaksanaan pre-test dan post-test.

Metode analisis data yang digunakan dalam penelitian ini adalah metode induksi statistik, analisis data untuk metode ini adalah data pada hasil belajar siswa, yang tercermin dalam perbedaan dalam skor rata-rata hasil siswa. Untuk menganalisis tingkat hasil belajar dari kedua kelompok, menggunakan pre-test dan post-test. Hipotesis diuji menggunakan rumus_TTest Independent menggunakan program pengolahan data SPSS 13.

\section{Hasil Penelitian}

Peneliti mengadakan penelitian ini enam pertemuan, dan mengadakan empat pertemuan dalam penerapan metode mim-mem untuk mengembangkan keterampilan berbicara. Dua kali pertemuan mereka diuji untuk pre-test dan post-test. Peneliti pelaksnakan dalam kelompok eksperimen seminggu sekali selama 90 menit.

\section{Efektifitas Penggunaan Metode Mim-Mem Untuk Mengembangkan Keterampilan Berbicara}

Peneliti dalam subjek ini menjelaskan detail dari studi lapangan, Terutama berkenaan dengan keefektifan metode mim-mem dalam perkembangan aspek keterampilan berbicara di MTsN Lampihong dalam kelompok eksprimen. 
Muhammad Iqbal: Penggunaan Metode Mim-Mem Untuk Mengembangkan Keterampilan Berbicara

Setelah peneliti mengumpulkan data dan kemudian menganalisa penggunaan metode mim-mem untuk mengembangkan keterampilan berbicara di MTsN Lampihong, Hasil nilai rata-rata kelas eksperimen dan kelas kontrol ketika pre-test tidak jauh berbeda yakni pada kelas eksperimen mencapai nilai rata-rata 63,66 dan kelas kontrol mencapai nilai rata-rata 64 yang berarti kemampuan siswa dalam keterampilan berbicara ini termasuk pada tingkat yang maqbul. Dengan demikian jelas bahwa kemampuan berbicara siswa umumnya maqbul.

Namun, Berdasarkan hasil yang diperoleh dalam kelompok eksperimen pada pre-test dan post-test telah menemukan perbedaan yang signifikan di antara keduanya dan karena pengaruh dari variabel eksperimen. Hasil nilai rata-rata dari kelas eksperimen setelah mengadakan post-test nilai rata-rata siswa mencapai 81 yang berarti kemampuan siswa dalam keterampilan berbicara pada tingkat jayyid jiddan. Dengan demikian jelas bahwa kemampuan berbicara siswa pada umumnya jayyid jiddan. Sedangkan hasil rata-rata siswa kelas kontrol setelah mengadakan post-test tidak jauh berbeda dengan nilai pre-test yakni 66,33 yang berarti kemampuan siswa dalam keterampian berbicara ini masih pada tingkat maqbul. Oleh karena itu, Hasil penelitian ini dapat disimpulkan sebagai berikut bahwa penggunaan metode mim-mem dalam rangka untuk meningkatkan pengembangan keterampilan siswa berbicara sangat efektif karena nilai rata-rata berbicara kelas eksperimen adalah 83 dan nilai rata-rata kelas kontrol adalah 66,76. dari perhitungan di atas, tampak bahwa nilai T-hitung 6,507 dengan derajat bebas 28. Hal ini memberikan nilai sig(2-tailed) sebesar 0,000 yang mengandung makna bahwa perbedaan hasil nilai kelas eksperimen dan kelas kontrol keduanya signifikan.

\section{Simpulan}

Sebagai akhir dalam pembahasan ini maka akan dikemukakan simpulan yang diperoleh dari paparan data, temuan peneliti dan pembahasan yang diambil dari peneitian ini adalah sebagai berikut:

1. Tahap pertama yang dilakukan peneliti sebelum menerapkan metode pembelajaran mimicry-memorization adalah mengadakan tes awal (pre test). Penerapan metode mimicry-memorization pada mata pelajaran bahasa Arab maharah kalam terdiri dari 2 kelas. Kelas eksperimen yang menggunakan metode mimicry-memorization terdiri atas 6 pertemuan, 
Muhammad Iqbal: Penggunaan Metode Mim-Mem Untuk Mengembangkan Keterampilan Berbicara

dan kelas kontrol dilakukan dalam 2 pertemuan. Penerapan metode pembelajaran mimicry-memorrization di MTsN Lampihong menjadi 3 tahap, yaitu: a) tahap awal, b) tahap inti, dan c) tahap akhir.

a) Tahap awal

Peneliti memulai kegiatan pembelajaran dengan mengucapkan salam dan mengajak peserta didik untuk membaca basmalah bersama. Selanjutnya mengecek kehadiran peserta didik. Peneliti juga menyampaikan tujuan dari pembelajaran pada hari itu serta menyampaikan materi yang akan dipelajari yaitu maharah kalam dengan tema tentang المواية. Kemudian peneliti melakukan tanya jawab kepada peserta didik seputar materi yang akan dipelajari untuk merangsang respon peserta didik. Tujuan tanya jawab ini yaitu untuk mengetahui tingkat pemahamaan peserta didik mengenai materi.

b) Tahap Inti

Penyajian dialog atau bacaan pendek yang dibacakan oleh guru berulang kali, sedangkan pelajar menyimaknya tanpa melihat pada teksnya. Peniruan dan penghapalan dialog atau bacaan pendek dengan cara meniru setiap kalimat secara serentak dan menghapalkannya.

Memasuki kegiatan inti peneliti menyampaikan materi dengan melafalkan hiwar dan meminta peserta didik untuk menirukannya secara bersama-sama. Peneliti berusaha untuk membuat peserta didik aktif menirukan hiwar yang disampaikan oleh peneliti hingga fasih dan benar. Disela-sela peserta didik menirukan hiwar yang disampaikan peneliti, peneliti menyelipkan pertanyaan-pertanyaan yang berkaitan dengan materi sehingga peserta didik tidak merasa bosan. Penyajian pola-pola kalimat yang terdapat dalam hiwar yang dianggap sulit karena terdapat struktur atau ungkapan-ungkapan yang sulit. Hal ini bisa dikembangkan dengan drill dengan metode ini dilatih struktur dan mufradat. Setelah menyampaikan materi peneliti menunjuk beberapa peserta didik secara acak untuk mempraktekkan hiwar kedepan kelas. Selanjutnya peneliti memberikan kesempatan pada peserta didik yang ingin bertanya berkaitan materi yang belum mereka fahami.

c) Tahap Akhir

Di akhir pembelajaran, peneliti bersama-sama peserta didik membuat kesimpulan tentang materi yang baru saja dipelajari, yaitu tentang الهواية. 
Muhammad Iqbal: Penggunaan Metode Mim-Mem Untuk Mengembangkan Keterampilan Berbicara

Tak lupa peneliti memberikan pesan moral kepada peserta didik, serta meminta peserta didik untuk mengulang materi yang telah diajarkan di rumah. Selanjutnya peneliti menutup pembelajaran dengan mengajak peserta didik untuk membaca hamdallah bersama-sama, dan pertemuan diakhiri dengan mengucap salam.

Pada pertemuan ke enam pada kelas eksperimen dan pada kelas kontrol, peneliti memberikan tes akhir. Tes tersebut dilakukan untuk mengetahui hasil belajar peserta didik setelah diterapkannya metode mimicry-memorization.

2. Pembelajaran dengan penggunaan metode pembelajaran mimicrymemorization dapat meningkatkan hasil belajar peserta didik di MTsN Lampihong pada maharah kalam mengalami peningkatan mulai dari pre test, hasil nilai rata-rata kelas eksperimen dan kelas kontrol ketika pre-test tidak jauh berbeda yakni pada kelas eksperimen mencapai nilai rata-rata 63,66 dan kelas kontrol mencapai nilai rata-rata 64 yang berarti kemampuan siswa dalam keterampilan berbicara ini termasuk pada tingkat yang maqbul. Dengan demikian jelas bahwa kemampuan berbicara siswa umumnya maqbul.

Namun, Berdasarkan hasil yang diperoleh dalam kelompok eksperimen pada pre-test dan post-test telah menemukan perbedaan yang signifikan di antara keduanya dan karena pengaruh dari variabel eksperimen. Hasil nilai rata-rata dari kelas eksperimen setelah mengadakan post-test nilai rata-rata siswa mencapai 81 yang berarti kemampuan siswa dalam keterampilan berbicara pada tingkat jayyid jiddan. Dengan demikian jelas bahwa kemampuan berbicara siswa pada umumnya jayyid jiddan. Sedangkan hasil rata-rata siswa kelas kontrol setelah mengadakan post-test tidak jauh berbeda dengan nilai pre-test yakni 66,33 yang berarti kemampuan siswa dalam keterampian berbicara ini masih pada tingkat maqbul.

Maka, berdasarkan analisis tersebut, dapat disimpulkan terdapat perbedaan yang signifikan antara kelas yang menggunakan metode pembelajaran mimicry-memorization dengan kelas yang tidak menggunakan metode pembelajaran mimicry-memorization. Hasil belajar siswa meningkat dan jauh lebih baik setelah diterapkannya metode 
Muhammad Iqbal: Penggunaan Metode Mim-Mem Untuk Mengembangkan Keterampilan Berbicara

pembelajaran mimicry-memorization dibuktikan dengan meningkatnya jumlah siswa yang nilainya berada di atas KKM (Kriteria Ketuntasan minimal). metode pembelajaran mimicry-memorization terbukti efektif apabila diterapkan pada pembelajaran bahasa Arab khususnya maharah kalam sebab mampu meningkatkan hasil belajar siswanya dan minat para siswa untuk belajar bahasa Arab serta telah dilaksanakan sesuai dengan prinsip-prinsip yang berlaku pada metode pembelajaran mimicrymemorization. 
Muhammad Iqbal: Penggunaan Metode Mim-Mem Untuk Mengembangkan Keterampilan Berbicara

\section{DAFTAR PUSTAKA}

'Adas, Abdurrahman. 1999. Asasiyat al bahtsu at tarbawi, Uman: Darul Furqan Dahlan, Juairiyah. 1992. Metode Belajar Mengajar Bahasa Arab. Surabaya: ALIKHLAS

Effendy, Ahmad Fuad. 2009. Metodologi Pengajaran Bahasa Arab. Malang: Misykat

Hermawan, Acep.2013. Metodologi Pembelajaran Bahasa Arab. Bandung: Remaja Rosada Karya

Iskandarwassid, 2009. Strategi Pembelajaran Bahasa. Bandung: Rosdakarya

Madkur, Ali Ahmad.2002. Tadris Funun Al-Lugah Al-Arabiyah. Al-Qahirah: Darul Fikri Al-Araby

Malibary, A.Akrom1976. Pedoman Pengajaran Bahasa Arab Pada Perguruan Tinggi Agam/I.A.I.N.Jakarta: Depag R.I

Mufarokah, Anissatul. 2009. Strategi Belajar Mengajar, Yogyakarta: TERAS

Muhtadi Anshor, Ahmad. 2009. Pengajar Bahasa Arab; Media Dan MetodeMetodenya. Yogyakarta: TERAS

Mustofa, Syaiful. 2011. Strategi Pembelajaran Bahasa Arab Inovatif. Malang: UIN Maliki Pres

Nuha, Ulin.2012. Metodologi Super Efektif Pembelajaran Bahasa Arab. Jogjakarta: DIVA Press

Sayyid Mansur, Abdul Majid. 1983. Sikolujiah Al-Wasail At-Ta'limiah Wa Wasail Tadris Al-Lugah Al-Arabiayah. Riyadh: Darul Ma'arif

Sugiono. 2012. Metode Penelitian pendidikan, Pendekatan Kuantitatif, Kualitatif, dan R\&D .Bandung: Alfabeta 